\title{
Bacillus cereus and Bacillus subtilis used as probiotics in rotifer (Brachionus plicatilis) cultures
}

Iván Murillo and Luisa Villamil *

Universidad de Bogotá Jorge Tadeo Lozano, Santa Marta, Colombia.

\begin{abstract}
Since live food is a key factor in fish and invertebrate larvae rearing, the objective of this study was to evaluate the probiotic potential of two Gram positive Bacillus species: Bacillus cereus (CCBM-2) and Bacillus subtilis (CCBM64), originally isolated from marine sediments in the Colombian Caribbean, in rotifer Brachionus plicatilis cultures. The enzymatic activity and antibacterial activity against pathogens of $B$. cereus and $B$. subtilis were measured in vitro. Direct supplementation of the rotifer culture water with both bacteria was also carried out and the effect was measured in vivo by estimating the density of rotifers and bacterial counts in the culture. The results indicated that extracellular products of both bacteria strongly inhibited the growth of Aeromonas hydrophila and Vibrio alginolyticus isolated from diseased fish. Enzyme API ZYM assays showed that both bacteria have esterase lipase, leucine arylamidase, acid phosphatase, lipase, and Naphthol-AS-BI- phosphohydrolase activities. Furthermore, it was observed that the addition of $B$. subtilis to the rotifer culture water resulted in a significant increase in rotifer numbers and a reduction of Vibrio levels. $B$. subtilis appears to be a promising probiotic for rotifer cultures, but further research is required to determine the capacity in controlling $A$. hydrophila and $V$. alginolyticus when administered via rotifers to fish larvae.
\end{abstract}

Keywords: Probiotic; Rotifers; Brachionus plicatilis; Bacillus cereus; Bacillus subtilis

\section{Introduction}

Rotifers are widely used as first food in the culture of several marine species, although they represent a significant vector for disease transmission since they carry a large bacterial load in their digestive tract $[1,2]$. Bacteria in rotifers could be transferred by ingestion $[2,3]$, but could also be transferred through contaminated seawater [4]. It has also been shown that selected bacterial inoculation plays a major role in the productivity of rotifer cultures, affecting mainly rotifer abundance and variability in their numbers within replicate cultures $[5,6]$. Fish larvae are susceptible to infection and high mortalities caused by opportunistic and pathogenic bacteria present in live prey [7]. This fact was demonstrated when survival was increased in fish larvae fed with axenic rotifers [8]. In order to treat and even prevent diseases in aquaculture, wide spectrum antibiotics have been frequently applied. However, there is great concern regarding this approach since it could favour the appearance of resistant pathogenic bacteria, and may cause alterations of aquatic environments and microbial communities due to the long half-life in the water of some chemicals, such as oxytetracycline [9].

A disease preventive method that could improve the host nonspecific immune defenses and at the same time, inhibit or control pathogenic bacteria is desirable. Prophylactic methods such as the use of vaccines have been limited since at early larval stages, fish rely mostly on the non-specific immune responses [10]. Probiotics are live microbial additives that confer a variety of beneficial effects on the host principally by modifying its enteric microbial community to increase food utilization and/or enhancing its nutritional value. Probiotics also appear to enhance the host response towards disease, and improve the quality of the rearing environment [11].

The introduction of selected bacterial strains into the food chain has been proposed as a alternative disease treatment. Lactobacillus plantarum and Bacillus spp. spores have been reported to decrease the amount of Vibrionaceae in rotifers fed with these additives, and subsequently increase weight and survival of turbot larvae [12]. Also, dietary Bacillus subtilis has been reported to cause an increase in the growth of tilapia Oreochromis niloticus [13], and to enhance the immune responses of fish [14]. Furthermore, the addition of Bacillus spp. to the rearing water can increase survival and net production of channel catfish improving water quality [15]. In shrimp, other studies suggest stimulation of the immune response in response to Bacillus treatment as elevated L. vannamei survival levels were observed during Vibrio harveyi and White Spot Syndrome [16], and enhancemed of haemocyte counts and superoxide dismutase activities have also been reported [17].

It is well known that bacteria of the Bacillus genus have strong adaptability to diverse conditions and that several species produce highly resistant spores; they have been isolated from fish [18-20], soft corals and sponges [21] as well as other marine invertebrates [22,23]. One of the advantages of using Bacillus spp. as probiotics in aquaculture is that they are unlikely to use genes from Gram negative bacteria (e.g., Vibrio) that may confer antibiotic resistance [24]. Since rotifers are an important and costly live food for rearing larval fish and invertebrates, and could also be vectors for pathogenic bacteria entry, the present study was designed to assess the probiotic potential of Bacillus cereus and Bacillus subtilis, previously isolated from marine sediments, to increase rotifer production and control bacterial growth in rotifer cultures. Their antibacterial capacity and enzymatic activity of the probiotics were also studied in vitro.

*Corresponding author: Luisa Villamil, Universidad Jorge Tadeo Lozano, Programa de Biología Marina, Carrera 2\#11-68, Edificio Mundo Marino. E Rodadero, Santa Marta, Colombia, Tel: 575422 9334; E-mail: luisa.villamil@ utadeo.edu.co

Received July 20, 2011; Accepted October 14, 2011; Published October 24, 2011

Citation: Murillo I, Villamil L (2011) Bacillus cereus and Bacillus subtilis used as probiotics in rotifer (Brachionus plicatilis) cultures. J Aquac Res Development S1:007. doi:10.4172/2155-9546.S1-007

Copyright: (c) 2011 Murillo I, et al. This is an open-access article distributed under the terms of the Creative Commons Attribution License, which permits unrestricted use, distribution, and reproduction in any medium, provided the original author and source are credited. 
Citation: Murillo I, Villamil L (2011) Bacillus cereus and Bacillus subtilis used as probiotics in rotifer (Brachionus plicatilis) cultures. J Aquac Res Development S1:007. doi:10.4172/2155-9546.S1-007

\section{Materials and Methods}

\section{Bacterial strains}

B. cereus (CCBM-2) and B. subtilis (CCBM-64) were obtained from the Natural History Museum of the Marine Research Institute INVEMAR (Santa Marta, Colombia) and originally isolated from marine sediments of the Colombian Caribbean. The Aeromonas hydrophila strain was originally isolated from tilapia (Oreochromis spp.) and kindly donated by Dr. Carlos Iregui, National University of Colombia. Vibrio alginolyticus was isolated from diseased Jack fish (Caranx hippos) housed at a local aquarium.

Bacillus strains were grown on trypticase soy agar A. hydrophila on trypticase soy broth (TSA and TSB, respectively, Oxoid, Cambridge, $\mathrm{UK}$ ), and $V$. alginolyticus in TSB supplemented with $1 \%$ of $\mathrm{NaCl}$, all at room temperature (R.T.). For long-term preservation, bacteria were frozen (- $80 \mathrm{C}$ ) in TSB with $15 \%$ glycerol.

\section{In vitro antibacterial activity of extracellular products (ECPs) from B. cereus and B. Subtilis}

The extraction of extracellular products (ECPs) from probiotic bacteria was performed according to Cabo et al. [25]. Briefly, B. cereus (CCBM-2) and B. subtilis (CCBM- cultures were grown overnight in TSB at R.T.. After incubation, cultures were separated by centrifugation at $500 \mathrm{x} \mathrm{g}$ for $30 \mathrm{~min}$. The supernatants were filtered $(0.45 \mu \mathrm{m}$ filter $)$, buffered at $\mathrm{pH} 6.0$, and stored in aliquots at $-80^{\circ} \mathrm{C}$. A. hydrophila was grown overnight at R.T. in TSB and $V$. alginolyticus in TSB $+1 \% \mathrm{NaCl}$. The assays were performed in triplicate in a 96 well plate by dispensing $50 \mu \mathrm{l}$ of the bacterial suspension $\left(10^{8}\right.$ colony forming units (CFU) $\mathrm{ml}$ $\left.{ }^{1}\right)$ per well with $50 \mu \mathrm{l}$ of the corresponding ECP treatment. Controls consisted of incubating the bacteria with TSB instead of ECPs. After 24 $\mathrm{h}$ incubation, changes in optical density $(600 \mathrm{~nm})$ of the culture aliquots were measured and the percentage of bacterial survival determined.

\section{Analysis of enzyme activity}

Enzyme production and activity were studied in B. cereus (CCBM2) and B. subtilis (CCBM-64) using the API ZYM kit (BioMerieux Marcy l'Etoile, France) according to the manufacturer's instructions. Briefly, bacteria were grown overnight on TSA at R.T. and re-suspended in API suspension medium at $10^{6} \mathrm{CFU} \mathrm{ml}^{-1}$. Then, $65 \mu \mathrm{l}$ of each sample was dispensed into each cupule and incubated for $4 \mathrm{~h}$. After incubation, the strips were read placing a surface-active agent (ZYM A reagent) in the cupules which facilitated solubilization of the ZYM B reagent in the medium. Color was allowed to develop for at least $5 \mathrm{~min}$, and graded on a scale from 0 to $5: 0$, negative reaction; $1,5 \mathrm{nmol} ; 2,10 \mathrm{nmol} ; 3$, $20 \mathrm{nmol} ; 4,30 \mathrm{nmol}$ and 5, $40 \mathrm{nmol}$ or higher of hydrolyzed substrate.

\section{Antibiotic sensitivity test}

Antibiotic resistance patterns of B. cereus (CCBM-2) and B. subtilis (CCBM-64) were determined by the disk diffusion method on MuellerHinton agar (Oxoid, Cambridge, UK) supplemented with $1 \% \mathrm{NaCl}$. The following concentrations of antibiotics were used: ampicillin, 10 $\mu \mathrm{g}$ disk $^{-1}$; chloramphenicol, $30 \mu \mathrm{g}$ disk $^{-1}$; nitrofurantoin, $300 \mu \mathrm{g}$ disk $^{-1}$; oxolinic acid, $2 \mu \mathrm{g}$ disk $^{-1}$; oxytetracycline, $30 \mu$ disk $^{-1}$; streptomycin, 10 $\mu \mathrm{g}$ disk $^{-1}$; tetracycline, $30 \mu \mathrm{g} \mathrm{disk}^{-1}$; trimethroprim-sulfamethoxazole, 25 $\mu \mathrm{g}$ disk $^{-1}$ and ciprofloxacin $5 \mu \mathrm{g}$ disk $^{-1}$.

\section{Rotifers and culture supplementation with $B$. subtilis and $B$. cereus}

Rotifers (Brachionus plicatilis) were hatched from cysts following the supplier's instructions (Aquatic Eco-Systems, Florida, USA) and cultured at $25^{\circ} \mathrm{C}$ in 21 conical tanks with seawater ( 20 ppt salinity) with gentle aeration. All rotifer cultures were fed Roti-Rich ${ }^{\circledast}$ (Florida Aqua Farms, Florida, USA) at $0.2 \mathrm{mg} \mathrm{ml}^{-1}$; this product is based on yeast, microalgae, vitamins and specific essential trace elements.

Rotifer cultures were maintained in $250 \mathrm{ml}$ Erlenmeyer flasks when supplemented with $B$. subtilis and B. cereus. The experiments started with an initial density of 40 rotifers $\mathrm{ml}^{-1}$ and three different treatments were assayed; $1: B$. subtilis at $10^{7} \mathrm{CFU} \mathrm{ml}^{-1}, 2: B$. cereus at $10^{7} \mathrm{CFU} \mathrm{ml}$ and 3: a control group with no bacterial supplementation. In order to evaluate rotifer growth, an optical microscope was used to count the number of individuals in Sedgwick-Rafter plates at day 1, 3 and 6 , reporting data as rotifers $\mathrm{ml}^{-1}$. Experiments were conducted in triplicate.

\section{Characterization of bacteria associated with the rotifer culture}

Samples of rotifers were filtered ( $50 \mu \mathrm{m}$ mesh), rinsed twice with 10 $\mathrm{ml}$ of sterile seawater (SSW), resuspended in $1 \mathrm{ml}$ of SSW, homogenized aseptically in a glass homogenizer and transferred to sterile tubes. In order to determine the bacterial load, samples were serially diluted and $100 \mu \mathrm{l}$ of each dilution was spread plated. Total viable counts were performed on marine agar media (M.A.; Difco, BD, Franklin Lakes, NJ, USA) and presumptive Vibrio counts on Thiosulfate Citrate Bile Sucrose Agar (TCBS). Plates were incubated aerobically for five days at $26^{\circ} \mathrm{C}$, after this time the colonies were counted and the number of bacteria was calculated as $\mathrm{CFU} \mathrm{ml}{ }^{-1}$.

\section{Statistical analysis}

Results were expressed as means \pm standard error. All statistical analyses were evaluated using the Excel 2007 (Microsoft ${ }^{\circ}$ ) software The data were compared using Mann-Whitney and the multiple sample comparison Kruskal Wallis tests (Statgraphics Centurion XV). Differences among treatments were considered significant at $\mathrm{P}<0.05$.

\section{Results}

In vitro antibacterial activity of extracellular products (ECPs) from B. cereus and B. Subtilis

It was found that both B. cereus (CCBM-2) and B. subtilis (CCBM-

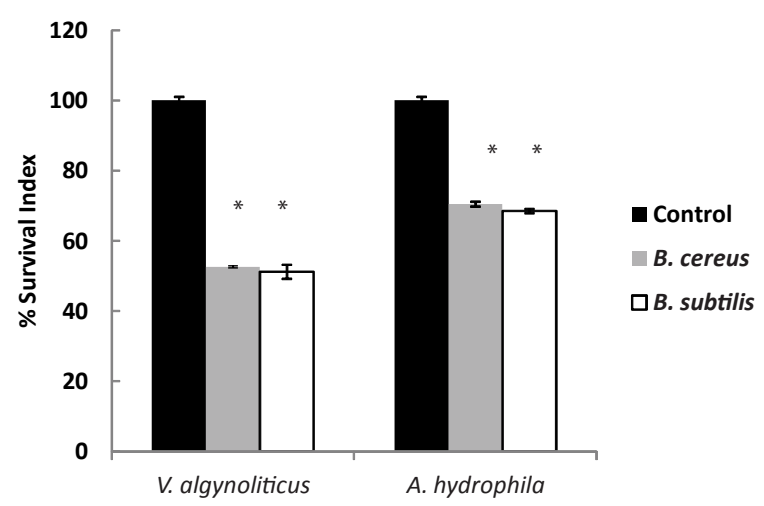

Figure 1: Growth inhibition of $V$. algynoliticus and $A$. hydrophila by incubation with ECPs of Bacillus cereus (CCBM-2) and Bacillus subtilis (CCBM-64), after $24 \mathrm{~h}$. Data are presented as the mean percentage of bacterial survival index and standard deviation of three different experiments. *Significantly lower growth than the mean growth observed in controls incubated with MRS $(\mathrm{P}<0.05)$ 
64) ECPs were able to significantly inhibit the growth of V. alginolyticus and $A$. hydrophila after $24 \mathrm{~h}$ of incubation, and reduced $V$. alginolyticus and $A$. hydrophila survival by approximately $50 \%$ and $30 \%$ of the initial levels, respectively (Figure 1).

\section{Analysis of the enzyme activity}

API ZYM assays revealed that B. cereus and B. subtilis produced esterase lipase (C8), leucine arylamidase, acid phosphatase, lipase, and naphthol-AS-BI-phosphohydrolase, while alkaline phosphatase and esterase (C4) were only produced by $B$. cereus and valine arylamidase by $B$. subtilis (Table 1 ).

\section{Antibiotic sensitivity test}

From the nine antibiotics tested, both B. cereus and B. subtilis appeared to be resistant to trimethroprim-sulfamethoxazole, ampicillin and oxolinic acid. Only B. cereus was resistant to ciprofloxaxine. $B$. cereus was susceptible to nitrofurantoin, tetracycline, oxytetracycline and highly susceptible to streptomycin, and chloramphenicol. $B$. subtilis was highly susceptible to ciprofloxaxine, oxytetracycline and tetracycline.

\section{B. subtilis and B. cereus administration to rotifer cultures}

Bacillus addition to rotifer cultures significantly affected the rotifer population dynamics. After 3 days of supplementation with $B$.

\begin{tabular}{llll}
\hline Enzyme & Substrate & B. cereus (nmol) & B. subtilis (nmol) \\
\hline $\begin{array}{l}\text { Alkaline phospha- } \\
\text { tase }\end{array}$ & $\begin{array}{l}\text { 2-naphthyl phos- } \\
\text { phate }\end{array}$ & 5 & 0 \\
$\begin{array}{l}\text { Esterase (C4) } \\
\begin{array}{l}\text { 2-naphthyl butyrate } \\
\text { (C8) }\end{array}\end{array}$ & $\begin{array}{l}\text { 2-naphthyl cap- } \\
\text { rylate }\end{array}$ & 20 & 0 \\
Lipase (C 14) & $\begin{array}{l}\text { 2-naphthyl myris- } \\
\text { trate }\end{array}$ & 5 & 20 \\
$\begin{array}{l}\text { Leucinearylami- } \\
\text { dase }\end{array}$ & $\begin{array}{l}\text { L-leucyl-2-naph- } \\
\text { thylamine }\end{array}$ & 20 & 5 \\
$\begin{array}{l}\text { Valinearylamidase } \\
\text { L-leucyl-2-naph- } \\
\text { thylamine }\end{array}$ & 0 & 20 \\
2-naphthyl phos- & 30 & 5 \\
$\begin{array}{l}\text { phate } \\
\text { Naphthol-AS-BI- } \\
\text { phosphohydrolase }\end{array}$ & $\begin{array}{l}\text { Naphthol-AS-BI- } \\
\text { phosphate }\end{array}$ & 5 & 20 \\
\hline
\end{tabular}

Table 1: Enzymatic activity of viable Bacillus cereus (CCBM-2) and Bacillus subtilis (CCBM-64).

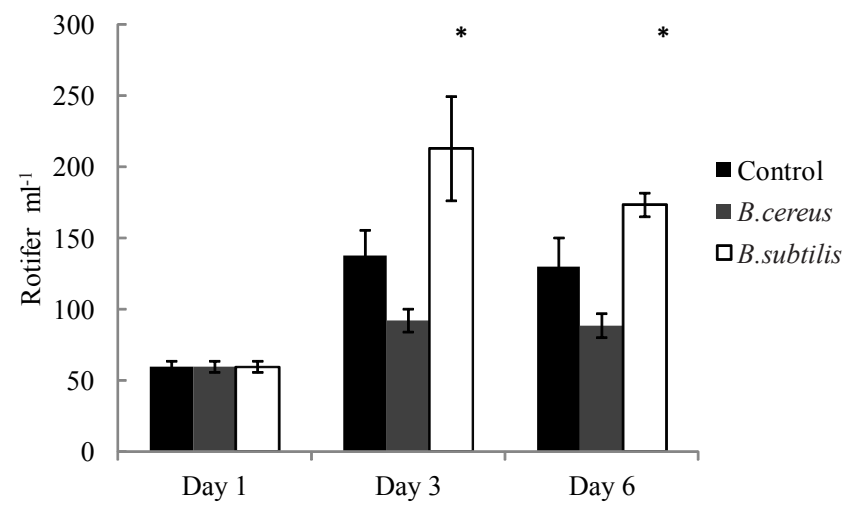

Figure 2: Rotifer counts after 3 and 6 days supplementation of $B$. cereus

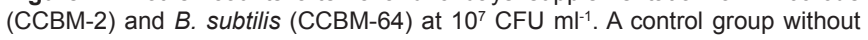
bacteria is also included. Data are presented as the mean number of rotifer per $\mathrm{ml}$ and standard error of three different experiments. * Significant differences in rotifer number among treatments $(P<0.05)$.

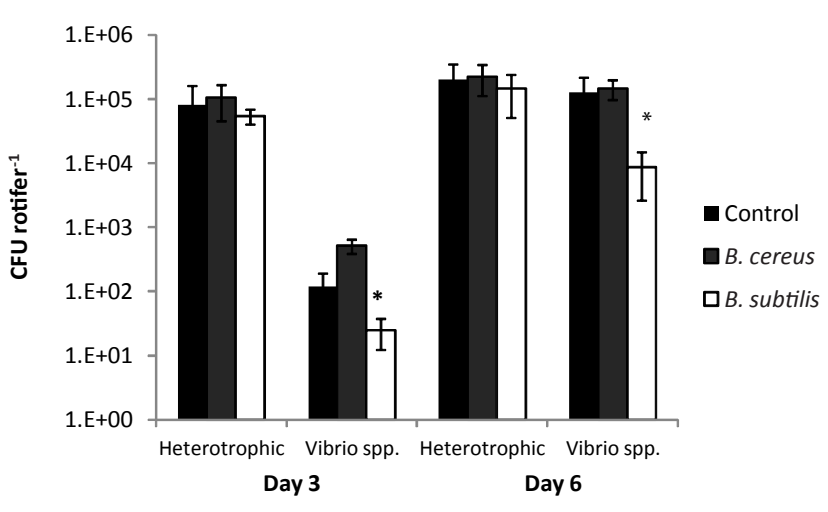

Figure 3: Total heretotrophic bacteria (M.A.) and Vibrio spp.(TCBS)from rotifer B. plicatilis cultures supplemented with Bacillus cereus (CCBM-2)and Bacillus subtilis (CCBM-64) at $10^{7} \mathrm{CFU} \mathrm{\textrm {ml } ^ { - 1 }}$. A control group without bacteria supplentation is also included. Data are presented as the mean CFU rotifer ${ }^{-1}$ and standard error of three different experiments. * Significant differences in bacterial number among treatments $(P<0.05)$

subtilis, the rotifer numbers more than doubled in comparison with the control group. In the case of $B$. cereus, a decrease in the number of rotifers was observed (Figure 2). After 6 days of incubation, the culture supplemented with $B$. subtilils showed a higher rotifer number than the non-supplemented control culture (Figure 2).

\section{Characterization of bacteria associated to the rotifer culture}

In the case of samples plated on the marine agar media (a medium that contains nutrients necessary to cultivate a broad spectrum of heterotrophic marine bacteria) no statistically significant differences were found in the number of $\mathrm{CFU} \mathrm{ml} \mathrm{m}^{-1}$ among the three treatments studied (Figure 3). On the other hand, the number of CFUs grown on TCBS, which is an agar used for the selective isolation of Vibrio spp., was significantly lower than the number of bacteria grown on marine agar media. A significant reduction of presumptive Vibrio spp. levels at both day 3 and day 6 was observed in the B. subtilis treated rotifers in comparison to control group (Figure 3).

\section{Discussion}

Bacillus strains are suitable as probiotics for aquaculture as they are commonly found as part of the microbiota in fresh and marine water, as well as in the gastrointestinal tract of animals [26]. The control of bacterial load by the addition of probiotic bacteria, most frequently sought for the elimination of pathogenic bacteria, has been shown to be an effective treatment to increase the productivity and health status of cultured fish [27-29].

Here we report, a strong antibacterial activity of B. cereus (CCBM2) and B. subtilis (CCBM-64) ECPs against $V$. alginolyticus and $A$. hydrophila; however this strong inhibitory activity was not clearly found in vivo since only a slight decrease in heterotrophic bacterial levels was observed when rotifer cultures were supplemented with the selected Bacillus strains. Nevertheless, B. subtilis supplementation of rotifer cultures caused a significant decrease in Vibrio levels after 3 and 6 days of treatment. The results presented here also indicate that $B$. cereus and B. subtilis were susceptible to most antibiotics tested, which is a desirable characteristic in the selection of probiotic bacteria.

The production of antimicrobial agents and inhibitory substances has been described previously in other Bacillus species. For example, B. subtilis BT23, isolated from a shrimp culture pond significantly 
Citation: Murillo I, Villamil L (2011) Bacillus cereus and Bacillus subtilis used as probiotics in rotifer (Brachionus plicatilis) cultures. J Aquac Res Development S1:007. doi:10.4172/2155-9546.S1-007

inhibited $V$. harveyi under in vivo and in vitro conditions, however, the antagonistic activity was only effective when the probiotic was used at high concentrations $\left(10^{7}-10^{9} \mathrm{UFC} \mathrm{m}^{-1}\right)$ [30]. Additionally, B. subtilis found in the probiotic Biosporin was reported to inhibit Helicobacter pylori growth [31]. In the same manner, a non-proteinaceus extracellular product of $B$. cereus with cyanobacteriolytic activity has previously been described [32]. Other studies have shown that Bacillus pumilus significantly inhibited fish pathogens such as $V$. harveyi, Vibrio metschnikovi and V. alginolyticus and that Bacillus clausii has a strong antibacterial activity against Vibrio parahaemolyticus, V. metschnikovi and $V$. alginolyticus [33].

Furthermore, the addition of B. subtilis to the rotifer culture water induced an increase in rotifer numbers. This fact could be related to the production of bacteriocins by the probiotic bacteria that inhibit or regulate growth of harmful bacteria, and enzymes that could improve rotifer digestion and utilization of nutrients. It has been previously shown that B. subtilis produce large levels of extracellular proteases (exoproteases), which degrade proteins from the environment and are mainly encoded by two genes; aprE (subtilisin) and bpr (bacillopeptidase) [34]. Both B. cereus and B. subtilis showed an important enzymatic activity of esterase lipase (C8), leucine arylamidase, and acid phosphatase that may have a positive effect in the digestion of lipids in the gut [35]. Also, the production of $\beta 1,3$ glucanases by other Bacillus species, such as $B$. clausii, providing the potential to hydrolyze $\beta 1-3$ glucans has been described [36]. The production of these enzymes may increase rotifer nutrient uptake efficiency since they are important for the digestion of algae $[37,38]$. It is known that B. pumilus, isolated from fish gut, produce extracellular compounds with protease, amylase and cellulose activity that could play an important role in the fish nutrition [19].

Moreover, it was recently reported that fish diets supplementated with $B$. pumilus, and $B$. clausii at $10^{8}$ cells $\mathrm{g}^{-1}$ significantly improved the feed conversion ratio and allowed more efficient use of nutrients by the grouper Epinephelus coioides [39]. In the same manner, it has been demonstrated that $B$. subtilis supplied as a food complement in rainbow trout diets, reduced mortalities caused by pathogenic bacteria $[40,41]$. Also, B. pumilus have been shown to improve immune functions in gilthead bream Sparus aurata [21] and Nile tilapia Oreochromis niloticus [18].

Other probiotics such as Lactobacillus plantarum, Lactobacillus helveticus and Lactococcus lactis have also been shown to increase rotifer growth $[12,42]$. The addition of other lactic acid bacteria such as Pediococcus acidilactici, has been also found to enhance rotifer population numbers, possibly associated to the production of vitamin B12 [43,44].

The results presented here indicated that B. subtilis (CCBM-64) was able to enhance rotifer growth, which was possibly associated with digestive enzyme production and microbial regulation. In the case of $B$. cereus (CCBM-2) use, care must be taken since even though $B$. cereus has never been associated with fish disease, there are some isolates that have been described as producers of two types of toxins that cause diarrhea and vomiting syndrome in humans [45]. Potential probiotic Bacillus species that enhance growth and resistance in food fishes could also be evaluated in ornamental fish culture since these fish stocks are routinely treated with antibiotics, and the larval stages of many of the species, as well as juveniles and adults rely on live food diets $[46,47]$. Further studies need to be carried out in order to purify and characterize the compounds that are responsible for the antibacterial activity of B. subtilis, and to determine the suitability of B. subtilis supplemented rotifers for the rearing of larval fish.

\section{Acknowledgements}

We would like to thank the members of the GICMOA research group of the University Jorge Tadeo Lozano (UJTL) for their technical assistance, the Natura History Museum of the Marine Research Institute INVEMAR, as well as the Veterinary Department of the National University of Colombia for the supply of bacteria. This research was possible through a UJTL204-05-09 award.

\section{References}

1. Munro PD, Henderson RJ, Barbour A, Birbeck TH (1999) Partial decontamination of rotifers with ultraviolet radiation: the effect of changes in the bacterial load and flora of rotifers on mortalities in start-feeding larval turbot. Aquaculture 170 229-244.

2. Skjermo J, Vadstein O (1999) Techniques for microbial control in the intensive rearing of marine larvae. Aquaculture 177: 333-343.

3. Plante S, Pernet F, Hache R, Ritchie R, Ji B, et al. (2007) Ontogenetic variations in lipid class and fatty acid composition of haddock larvae Melanogrammus aeglefinus in relation to changes in diet and microbial environment. Aquaculture 263: 107-121.

4. Prol-Garcia MJ, Planas M, Pintado J (2010) Different colonization and residence time of Listonella anguillarum and Vibrio splendidus in the rotifer Brachionus plicatilis determined by real-time PCR and DGGE. Aquaculture 302: 26-35.

5. Hagiwara A, Hamada K, Hori S, Hirayama K (1994) Increased sexua reproduction in Brachionus plicatilis (rotifera) with the addition of bacteria and rotifer extracts. J Exp Mar Biol Ecol 181: 1-8

6. Douillet PA (2000) Bacterial additives that consistently enhance rotifer growth under synxenic culture conditions. Evaluation of commercial products and pure isolates. Aquaculture 182: 249-260.

7. Tinh NT, Dierckens K, Sorgeloos P, Bossier $P$ (2008) A review of the functionality of probiotics in the larviculture food chain. Mar Biotechnol (NY) 10: 1-12.

8. Munro PD, Barbour A, Birkbeck H (1995) Comparison of the growth and survival of larval turbot in absence of culturable bacteria with those in the presence of Vibrio anguillarum, Vibrio alginolyticus, or a marine Aeromonas sp. Appl Environ Microbiol 61: 4425-4428.

9. Hektoen H, Berge JA, Hormazabal V, Yndestad M (1995) Persistence of antibacterial agents in marine sediments. Aquaculture 133: 175-184.

10. Mulero I, Sepulcre MP, Fuentes I, García-Alcázar I, Meseguer J, et al (2008) Vaccination of larvae of the bony fish gilthead seabream reveals a lack of correlation between lymphocyte development and adaptive immunocompetence. Mol Immunol 45: 2981-2989.

11. Gatesoupe FJ (1999) The use of probiotics in aquaculture. Aquaculture 180: 147-165.

12. Gatesoupe FJ (1991) Fish Nutrition in Practice, SJ Kaushik, P. Luquet (Eds.) Institut National de la Recherche Agronomique, Paris.

13. Gunther J, Jimenez-Montealegre R (2004) Efecto del probiótico Bacillus subtilis sobre el crecimiento y alimentación de tilapia (O. niloticus) y langostino (M. rosenbergii) en laboratorio. Rev Biol Trop 52: 937-943.

14. Villamil L, Novoa B (2009) Probiotics in Aquaculture. Probiotics: Production Evaluation and Uses in Animal Feed, 91-118. Perez Guerra N \& Pastrana Castro L (Eds). Research Signpost, Trivandrum, Kerala, India.

15. Queiroz JF, Boyd CE (1998) Effects of a bacterial inoculum in channel catfish ponds. J World Aquacult Soc 29: 67-73.

16. Balcázar JL, De Blas I, Zarzuela-Ruiz I, Cunningham D, Vendrell D, et al. (2006) The role of probiotics in aquaculture (Review). Vet Microbiol 114: 173-186.

17. Li K, Zheng T, Tian Y, Xi F, Yuan J, et al. (2007) Beneficial effects of Bacillus licheniformis on the intestinal microflora and immunity of the white shrimp Litopenaeus vannamei. Biotechnol Lett 29: 525-530.

18. Aly SM, Mohamed MF, John G (2008) Effect of probiotics on the survival, growth and challenge infection in Tilapia nilotica (Oreochromis niloticus). Aquacult Res 39: $647-656$

19. Ghosh K, Sen SK, Ray AK (2002) Characterization of bacilli isolated from the gut of rohu Labeo rohita fingerlings and its significance in digestion. J App Aquacul 12: 33- 42. 
Citation: Murillo I, Villamil L (2011) Bacillus cereus and Bacillus subtilis used as probiotics in rotifer (Brachionus plicatilis) cultures. J Aquac Res Development S1:007. doi:10.4172/2155-9546.S1-007

20. Sugita $H$, Hirose $Y$, Matsuo N, Deguchi $Y$ (1998) Production of the antibacterial substance by bacillus species strain NM12, an intestinal bacterium of Japanese coast. Aquaculture 165: 269-280.

21. Ivanova EP, Gorshkova NM, Nedashovskaya OI, Vysotsky MV, Svetashev VI, et al. (1999) Taxonomy of $B$. subtilis, B. pumilus and $B$. horti of marine origin. Mar Biol 25: 483-487.

22. Khandeparker L, Anil AC, Raghukumar S (2003) Barnacle larval destination: piloting possibilities by bacteria and lectin interaction. J Exp Mar Biol Ecol 289: 1-13.

23. Miyanishi N, Hamada N, Kabayashi T, Imada C, Watanabe E (2003) Purification and characterization of a novel extracellular beta-1-3 Glucanase produced by Bacillus clussi NM-1 Isolated from Ezo Abalone Haliotis discus hannai. J Biosci Bioeng 95: 45-51.

24. Rabinowitz JC, Roberts M (1986) Translational barriers limiting expression of $E$. coli genes in Bacillus and other Gram-positive organisms. In: Levy SB, Novick RP (eds) Banbury Report 24: Antibiotic Resistance Genes: Ecology, Transfer and Expression. Cold Spring Harbour Laboratory.

25. Cabo ML, Murado MA, González MP, Pastoriza L (1999) A method for bacteriocin quantification. J Appl Microbiol 87: 907-914.

26. Hong HA, Duc LH, Cutting SM (2005) The use of bacterial spore formers as probiotics. FEMS Microbiol Rev. 29: 813-835.

27. Picchietti S, Mazzini M, Taddei AR, Renna R, Fausto AM, et al. (2007) Effects of administration of probiotic strains on GALT of larval gilthead seabream: Immunohistochemical and ultrastructural studies. Fish Shellfish Immunol 22: 57-67.

28. Vine NG, Leukes WD, Kaiser H (2006) Probiotics in marine larviculture. FEMS Microbiol Rev. 30: 404-427.

29. Villamil L, Figueras A, Aranguren R, Novoa B (2003a) Non specific immune responses of turbot (Scopthalmus maximus L.) experimentally infected with a pathogenic Vibrio pelagius like. J Fish Dis 26: 321-329.

30. Tinh NT, Linh ND, Wood TK, Dierckens K, Sorgeloos P, et al. (2006) Interference with the quorum sensing systems in a Vibrio harveyi strain alters the growth rate of gnotobiotically cultured rotifer Brachionus plicatilis. J Appl Microbiol 103: 194-203.

31. Pinchuk IV, Bressollier P, Verneuil B, Fenet B, Sorokulova IB, et al. (2001) In vitro anti-Helicobacter pylori activity of the probiotic strain Bacillus subtilis 3 is due to secretion of antibiotics. Antimicrob Agents Chemother 45: 3156-3161.

32. Nakamura N, Nakano K, Sugiura N, Matsumara M (2003) A nove cyanobacteriolytic bacterium, Bacillus cereus, isolated from a eutrophic lake. J Biosci Bioeng 95: 179-184.

33. Sun $Y$, Yang $H$, Ling Z, Chang J, Ye J (2009) Gut microbiota of fast and slow growing grouper Epinephelus coioides. Afr J Microbiol Res 2009 3: 713-720.

34. Msadek T (1999) When the going gets tough: survival strategies and environmental signaling networks in Bacillus subtilis. Trends Microbiol 7: 201 207
35. Kim EY, Kim YH, Rhee MH, Song JC, Lee KW, et al. (2007) Selection of Lactobacillus sp. PSC101 that produces active dietary enzymes such as amylase, lipase, phytase and protease in pigs. J Gen Appl Microbiol 53: 111117.

36. Duc LH, Hong HA, Barbosa TM, Henriques AO, Cutting SM (2004) Characterization of Bacillus Probiotics Available for Human Use. Appl Environ Microbiol 70: 2161-2171.

37. Stahmann KP, Schmiz KL, Sahm H (1993) Purification and characterization of four extracellular 1,3- $\beta$-glucanases of Botrytis cinerea. J Gen Microbiol 139 2833-2840.

38. Zhu BW, Zhao JG, Yang J, Mikiro T, Zhang ZS, et al. (2008) Purification and partial characterization of a novel $\beta$-1,3-glucanase from the gut of sea cucumber Stichopus japonicus. Process Biochem 43: 1102-1106. http://www. sciencedirect.com/science/article/pii/S1359511308001839

39. Sun YZ, Yang HL, Ma RL, Lin WY (2010) Probiotic applications of two dominant gut Bacillus strains with antagonistic activity improved the growth performance and immune responses of grouper Epinephelus coioides. Fish Shellfish Immunol 29: 803-809.

40. Decamp O, Moriarty DJW, Lavens $P$ (2008) Probiotics for shrimp larviculture: review of field data from Asia and Latin America. Aquacult Res 39: 334-338.

41. Wang GX, Liu YT, Li FY, Gao HT, Lei Y, et al. (2010) Immunostimulatory activities of Bacillus simplex DR-834 to carp (Cyprinus carpio). Fish Shellfish Immunol 29: 378-387.

42. Harzevili ARS, Van Duffel $H$, Dhert P, Swings J, Sogerloos $P$ (1998) Use of a potential probiotic Lactococcus lactis AR21 strain for the enhancement of growth in the rotifer Brachionus plicatilis (Muller). Aquacult Res 29: 411-417.

43. Planas M, Vázques JA, Marqués J, Pérez-Lomba R, González MP, et al. (2004) Enhancement of rotifer (Brachionus plicatilis) growth by using terrestrial lactic acid bacteria. Aquaculture 240: 313-329.

44. Yu JP, Hino A, Ushiro M, Maeda M (1989) Function of bacteria as vitamin B12-producers during mass culture of the rotifer Brachionus plicatilis. Nippon Suisan Gakk 55: 1799-1806.

45. Spira WM, Goefert JM (1975) Biological characteristics of an enterotoxin produced by Bacillus cereus. Can J Microbiol 21: 1236-1246.

46. Martins ML, Mouriño JLP, Fezer GF, Buglione-Neto CC, Garcia P, et al. (2010) Isolation and experimental infection with Vibrio alginolyticus in the sea horse Hippocampus reidi Ginsburg, 1933 (Osteichthyes: Syngnathidae) in Brazil. Braz J Biol 70: 205-209.

47. Verner-Jeffreys D, Welch T, Schwarz T, Pond M, Woodward M (2009) High Prevalence of Multidrug-Tolerant Bacteria and Associated Antimicrobia Resistance Genes Isolated from Ornamental Fish and Their Carriage Water. PLoS One 4: 8388
This article was originally published in a special issue, Probiotic \& Prebiotic Applications in Aquaculture handled by Editor(s). Dr. Daniel L. Merrifield, University of Plymouth, UK; Prof. Zhigang Zhou, Chinese Academy of Agricultural Sciences, China 